\title{
COVID 19: Physiotherapy performance in a pediatric intensive care unit
}

\author{
Camila G Ribas*, Valéria C Neves, Emilly F de Souza, Adriana Koliski and José E Carreiro \\ Complexo Hospital de Clínicas da Universidade Federal do Paraná, Brazil
}

The severe acute respiratory syndrome coronavirus 2 (SARSCoV-2) is a new coronavirus who emerged in 2019 and causes Coronavirus Disease 2019 (COVID-19) that is highly contagious and differs from other respiratory viroses. The transmition occurs by human-to-human approximately 2 to 10 days prior to the individual becoming symptomatic [1-4].

The COVID-19 in children is often less severe than in adults. It is believed children were usually well cared for at home and might have relatively less opportunities to expose themselves to pathogens and/or sick patients. The angiotensin converting enzyme II (ACE2) is known as a SARS-CoV-2 /receptor and evidence has indicated that these receptors in children have less maturity and function than in adults. Making children less sensitive to the virus. Dong et al. observed that in $125(5.8 \%)$ children had severe or critical conditions. The proportion was higher in younger children $(10.6 \%$ at $<1$ year of age vs. $3 \% \geq 16$ years. In 13 critical cases, 7 (53.8\%) were younger than 1 year and only a 14 years old boy died [5-8].

According to recently published literature the evaluation of imaging exams of the most severe cases is of great relevance. The typical radiographic image when examining the chest tomography of pulmonar involvement is parenchymal destruction expressed as multiple bilateral ground-glass opacities and pulmonary consolidations. In children with severe infections, multiple lobar lesions may be present in both lungs $[9,10]$.

Physiotherapeutic assistance to patients diagnosed with COVID-19 must follow four fundamental principles: early identification, isolation, diagnosis and treatment. Besides that, it is important to establish and describe the new strategic of work process flow and training step by step the safety of this new process [11-16].

Physiotherapeutic procedures can be considered high risk when they include aerosol-generating, such as: aspiration of the airways, collection of secretion from the upper airways, the aid during of tracheal intubation and cardiorespiratory arrest manuevers. It is important to remember even direct handling of the patient for positioning, elective tracheal extubation, change of the barrier filters and adjustment/ fixation of tracheal tube are procedures of risk [11-15].

The role of the physiotherapist is so importante mainly related to the quality of care for this special pediatric patients in the COVID-19 pandemic. Although we need reinforcement in the validation of the many strategies used by physioterapist. It is important to remind that during intensive medical treatment of these patients even using protective pulmonary ventilation, sedation and neuromuscular blockers, this patients are at high risk of developing muscle weakness acquired in the ICU and consequently worsening their morbidity and mortality $[17,18]$.
In pediatric patients on mechanical ventilation, the use of the Oxygenation Index (OI) [(OI= $\left.\left.\mathrm{MAP} \times \mathrm{FiO}_{2} \times 100 / \mathrm{PaO}_{2}\right)\right]$, is an ideal index for the classification of pediatric ARDS severity [19-24]. The oxygenation index uses the mean airway pressure (MAP), oxygen fraction $\left(\mathrm{FiO}_{2}\right)$ and partial oxygen pressure in arterial blood $\left(\mathrm{PaO}_{2}\right)$. The degree of lung injury is classified as: mild acute respiratory distress syndrome (ARDS) $(4<\mathrm{OI}<8)$, moderate ARDS $(8<\mathrm{OI}<16)$ and severe ARDS (OI> 16) [19-25].

The strategy of monitoring and control of drive pressure at values $\leq 15 \mathrm{cmH}_{2} \mathrm{O}$ with plateau pressure limited to $28 \mathrm{cmH}_{2} \mathrm{O}$ becomes extremely important. These measures could avoid new damage to an already damaged lung [20-22].

A prepared, motivated and experienced team can directly influence the success of the treatment of COVID-19. The objectives must be well established, with treatment methods based on the best evidence combined with the domain of different technologies. Beyond the acute stage of disease the Physiotherapy will play a important role providing interventions with exercises, mobilization and early rehabilitation. This way, it will be possible to promote a functional recovery for survivors of critical illness associated with COVID-19.

\section{References}

1. del Rio C, Malani PN (2020) 2019 Novel Coronavirus Important Information for Clinicians. JAMA 323:1039-1040. [Crossref]

2. World Health Organization (2020) Coronavirus disease 2019 (COVID-19). Situation Report, 46.

3. Sohrabi C, Alsafi Z, O’Neill N, Khan M, Kerwan A, Al-Jabir A, et al. (2020) World Health Organization declares global emergency: A review of the 2019 novel coronavirus (COVID-19). Int J Surg 76: 71-76. [Crossref]

4. Guan WJ, Ni ZY, Hu Y, Liang WH, Ou CQ, He JX, et al. (2020) Clinical Characteristics of Coronavirus Disease 2019 in China. New Engl J Med 382: 1708-1720.

5. Dong Y (2020) Epidemiological Characteristics of 2143 Pediatric Patients With 2019 Coronavirus Disease in China. Pediatrics.

6. XU, Zhe (2020) Pathological findings of COVID-19 associated with acute respiratory distress syndrome. Lancet Respir Med 2020. [Crossref]

7. Zimmermann P, Curtis N (2020) Coronavirus Infections in Children Including COVID-19. The Pediatr Infect Dis J 39: 355-368 [Crossref]

8. Xing Y, Ni W, Wu Q (2020) Prolonged presence of SARS-CoV-2 in feces of pediatric patients during the convalescent phase, 2020.

*Correspondence to: Camila G Ribas, Complexo Hospital de Clínicas da Universidade Federal do Paraná, Brazil, E-mail: camilaribas@gmail.com

Received: April 10, 2020; Accepted: April 16, 2020; Published: April 20, 2020 
9. Wei Li, Huaqian Cui, Kunwei Li, Yijie Fang, Shaolin Li (2020) Chest computed tomography in children with COVID-19 respiratory infection. Pediatr Radiol 50: 796799. [Crossref]

10. Zhi-Min C, Fu J, Shu Q (2020) Diagnosis and treatment recommendations for pediatric respiratory infection caused by the 2019 novel coronavirus. World J Pediatr 5: 1-7. [Crossref]

11. Royal College of Paediatrics and Child Health (2020) COVID-19 - Guidance for paediatric services.

12. Recomendações do manejo fisioterapêutico no âmbito de urgência e emergência em pacientes com COVID-19. Nota técnica da câmara técnica de fisioterapia em urgência e emergência do conselho regional de fisioterapia e terapia ocupacional do rio de janeiro (CREFITO-2), 2020.

13. Martinez BP (2019) COVID-19: Papel do Fisioterapeuta em diferentes cenários de atuação. ASSOBRAFIR.

14. Aspectos Epidemiológicos e Atuação Do Fisioterapeuta Na Prevenção e Tratamento da COVID-19 Na População Infantil Em Ambiente Hospitalar - ASSOBRAFIR, 2019.

15. Ñamendys-silva A (2020) Respiratory support for patients with COVID-19 infection. Lancet Respir Med 8: e18. [Crossref]

16. Brasil, Ministério da Saúde - Protocolo de Manejo Clínico para o Novo Coronavírus, 2020.
17. Kress JP, Hall JB (2014) ICU-acquired weakness and recovery from critical illness. $N$ Engl J Med 370: 1626-1635. [Crossref]

18. Herridge MS, Tansey CM, Matte A, Tomlinson G, et al. (2011) Functional disability 5 years after acute respiratory distress syndrome. $N$ Engl J Med 364: 1293-1304. [Crossref]

19. Barbas CS (2014) Recomendações brasileiras de ventilação mecânica 2013. Parte I. Rev Bras Ter Intensiva 26: 89-121.

20. Amato, MBP (2015) Driving pressure and survival in the acute respiratory distress syndrome. N Engl J Med 372: 747-755. [Crossref]

21. Georgopoulos D, Xirouchaki N, Tzanakis N, Younes M (2016) Driving pressure during assisted mechanical ventilation. Respir Physiol Neurobiol 8: 484-493. [Crossref]

22. PALICC (2015) Pediatric acute respiratory distress syndrome: Consensus recommendations from the pediatric acute lung injury consensus conference. Pediatr Crit Care Med 16: 428-439. [Crossref]

23. Neto AS, Simonis FD, Barbas CSV, Biehl M, Determann RM, et al. (2014) Association between tidal volume size, duration of ventilation, and sedation needs in patients without acute respiratory distress syndrome: an individual patient data meta-analysis. Intensive Care Med 40: 950-957. [Crossref]

24. Cheifetz IM (2017) Pediatric ARDS. Respiratory Care 62: 718-731. [Crossref]

Copyright: $\odot 2020$ Ribas CG. This is an open-access article distributed under the terms of the Creative Commons Attribution License, which permits unrestricted use, distribution, and reproduction in any medium, provided the original author and source are credited. 